\title{
DISASTER RISK MANAGEMENT AND MEASUREMENT INDICATORS FOR CULTURAL HERITAGE IN TAIWAN
}

\author{
Y. N. Yen ${ }^{\text {a C. F. Cheng }}{ }^{\mathrm{a}, *}$, H. M. Cheng ${ }^{\mathrm{a}}$ \\ ${ }^{a}$ China University of Technology, 56 Sec. 3 Shin Long Rd., 116 Taipei, Taiwan - (alexyen, aabbyy, hungmc)@ cute.edu.tw
}

KEY WORDS: Cultural Heritage, Disaster Risk Management, Taiwan

\begin{abstract}
:
Under the influence of global climate change, the risk preparedness has become a universal issue in different research fields. In the conservation of cultural heritage, disaster risk management is becoming one of the major research topics. Besides researches on the theory and mechanism of disaster risk management, the tools for the performance of site managers to protect cultural heritage is another important issue that needs development.

UNESCO and ICOMOS have released some important documents on disaster risk management including its concept, identification, evaluation, mitigation, monitoring and resilience, etc. However, there is a big gap between concept and implementation in Taiwan. Presently there are 2000 monuments in Taiwan that hardly meet the modern code. First, based on international documents released, this research presents 13 disaster indicators on monuments and their environments. Next, 345 monuments in northern Taiwan are taken as examples to evaluate their risk situations with indicators designed in 2011. Some positive recommendations were given at the same time. As a result, a comparative evaluation was completed in 2012 and some key issues are found, such as too many electrical facilities, lack of efficient firefighting equipment, and a shortage of management mechanism, just to name a few. Through the improvement of the management, some major risk can be mitigated.

In 2013 14, this research took 23 national monuments from the 345 monuments to evaluate their risk situations and compare the differences between national and local monuments. Results show that almost all management mechanisms in the national monuments have been established and are running well. However, problems like inappropriate electrical facilities and insufficient monitoring equipment remain. In addition, the performance of private monuments is not as good as public ones. Based on the collected information and evaluation, this research develops safety measures of heritage conservation in two aspects. One is for researchers to measure the risk of the heritage; the other is for site managers to manage the risk of their monument with ease.

In conclusion, intendants of monuments in Taiwan have to develop more disaster risk management ideas to mitigate and prevent risks. In the meantime, the management and monitoring mechanisms available are helpful tools for risk mitigation. The awareness and training of the site managers are important issues for the implementation of risk prevention.
\end{abstract}

\section{INTRODUCTION}

Cultural heritage $(\mathrm{CH})$ and its environment have profound cultural, scientific, artistic and various other values that are irreversible and cannot be replaced. For the preservation and the sustainability of these precious properties, an efficient risk management mechanism based on the cultural value priority concept has become an important universal challenge in the 21st century. Compared with modern buildings, monument has its weakness in the environment, materials, structure and not strong enough to prevent or withstand disaster. Cultural Heritage Preservation Act (CHA) in Taiwan took effect in 2006. The cultural value priority concept declared in article 22 offers guidelines to establishing a proper risk management system that does not have to fit contemporary codes. This important idea has been realized in the field of conservation; however, there still is a gap in the implementation with firefighting department. Under the influence of the UNESCO World Heritage strategy and the Convention Concerning the Protection of the World Cultural and Natural Heritage, 1972, together with many relative international documents, the concept and implementation of conservation has taken the Outstanding Universal Value, OUV, as the most important issue and has been accepted as an international principle.

\footnotetext{
* Corresponding author.
} 
Besides that, the UNESCO, ICOMOS and ICCROM have released some important documents on disaster risk management including its concept, identification, evaluation, mitigation, monitoring and resilience, etc. to help the conservation of $\mathrm{CH}^{1}{ }^{1}$ In 2012, take world heritage site Petra as an example, the UNESCO provided an experience on the evaluation frame and surveying indicators. 《Disaster risk management of cultural heritage in urban areas - A Training Guide 》 by the ICCROM in 2014, focused on the risk management and its training for the historic urban districts.

The Nara document in 1994 highlighted the importance of authenticity and helping conservation under the value of cultural properties. Recently, under the influence of rapid social change and the trend of globalization, a conservation concept based on integrity, ${ }^{2}$ has been included as a key issue in taking care of the environment of monuments and sites. This concept not only concerns the protection of $\mathrm{CH}$ but also the development and the risk management. Five emphases are listed below:

1. The main purpose of the risk management plan is to protect the cultural value, including the tangible and intangible evidences of authenticity, integrity away from potential disasters.

2. The knowledge of disaster history, science, techniques and implementation experiences which were carried out by the $\mathrm{CH}$ together with their environment and supporting mechanism should be integrated into the risk management system to make contribution.

${ }^{1}$ (1)Herb Stovel, 《Risk Preparedness: A Management Manual for World Cultural Heritage》, ICCROM, 1998

(2)UNESCO, 《Case Studies on Climate Change and World Heritage 》, 2007

(3)UNESCO, 《 Managing Disaster Risks for World Heritage 》, 2010

(4)UNESCO and Katholieke Universiteit Leuven, Faculty of Engineering, Raymond Lemaire International Centre for Conservation, 《Risk management at Heritage Sites- A Case Study of the Petra World Heritage Site》, 2012

(5)ICOMOS-ICORP, Heritage and Resilience: Issues and Opportunities for Reducing Disaster Risks, 2013.

(6) ICCROM, 《Disaster Risk management of Cultural Heritage in Urban areas - A Training Guide》, 2014.

${ }^{2}$ Integrity together with the Authenticity was mentioned in the Venice Charter, 1964. The integrity was taken as a main review frame for the natural world heritage. Since 2005, in the operational guidelines for the implementation of the world heritage convention (OG), both integrity and authenticity were announced as a tool for the reviewing on the value of world heritage.

In the article 88 of OG,

Integrity is a measure of the wholeness and intactness of the natural and/or cultural heritage and its attributes. Examining the conditions of integrity, therefore requires assessing the extent to which the property:

(1) includes all elements necessary to express its Outstanding Universal Value;

(2)is of adequate size to ensure the complete representation of the features and processes which convey the property's significance;

(3) Suffers from adverse effects of development and/or neglect. This should be presented in a statement of integrity.
3. To establish a risk management mechanism is also a kind of cultural awareness as well and will be achieved by a well-planned and progressive action.

4. The cultural diversity, capability of the communities and their traditions should be considered in the risk management plan.

5. All the stakeholders are key members of the Plan.

The conservation experience in Taiwan mainly focuses on restoration of the main construction of monuments. Public participation and maintenance issues are less concerned. Consequently, it does not only squeeze the cycle for the next restoration but also cause high risk on the monuments. Therefore, it is important to establish a risk management plan for the cultural heritage based on the integrity concept.

\section{THE DISASTER-CAUSING CHARACTERISTICS OF MONUMENTS, HISTORIC BUILDINGS AND SETTLEMENTS IN TAIWAN}

\subsection{Monuments, Historic Buildings and Settlements in} Taiwan

There are 2000 built heritages in Taiwan, including 369 pure wood construction (18\%) together with 878 wood and masonry construction (43\%) are in high risk.

Table 1. CH in Taiwan (2015.03)

\begin{tabular}{|l|l|l|l|l|}
\hline Type & Number & Wood & $\begin{array}{l}\text { Wood and } \\
\text { masonry }\end{array}$ & others \\
\hline Monument & 806 & $140(17 \%)$ & $239(30 \%)$ & $427(53 \%)$ \\
\hline $\begin{array}{l}\text { Historic } \\
\text { buildings }\end{array}$ & 1182 & $227(19 \%)$ & $261(22 \%)$ & $694(59 \%)$ \\
\hline Settlement & 12 & $2(17 \%)$ & $9(75 \%)$ & $1(8 \%)$ \\
\hline Total & 2000 & $369(18 \%)$ & $509(25 \%)$ & $1122(57 \%)$ \\
\hline
\end{tabular}

\subsection{The disaster history of $\mathrm{CH}$ in Taiwan}

According to the basic plan for disaster prevention and mitigation, disasters can be divided into two major categories of natural and anthropogenic. In Taiwan, typhoons, floods, earthquakes, fire are the most significant disasters. ${ }^{3}$

The monuments affected by disaster in Taiwan for the past 50 years, $77 \%$ was basically a fire, that is, ${ }^{4}$ the $\mathrm{CH}$ dominated by timber construction, resistance to fire is most vulnerable to a variety of major disasters such as floods, earthquakes. In Taiwan, fire caused by earthquake is still the greatest impact for $\mathrm{CH}$.

The main monuments or historic buildings in Taiwan were constructed by wood and masonry. Compare with other disasters, the fire damage with earthquake caused the most severe than typhoons, floods, and its resilience is the weakest. This phenomenon in Japan's research is similar as well. ${ }^{5}$

3 National Disaster Prevention and Response Committee, Disaster Prevention and Response Basic Plan, 2007

4 Ya-Ning Yen 、 Su-Fen Yen , $\ulcorner$ Research of target requirement and operational organization assignment of cultural heritage disaster(III) $\lrcorner$, Ministry of Science and Technology , 2014

${ }^{5}$ Since the earthquake on March 11th, 2011, many research of the risk prevention had focused on the multiple hazards especially the fire caused by earthquake. The efficient equipment, simulation of disaster and escape routes is main 
However, there are many issues such as biological attack, material degradation, inappropriate usage and lack of maintenance may endanger a bigger part of the $\mathrm{CH}$. Normally; it's not so easy to solve all the risks in a short time, but the situation can be improved and mitigated by management approach.

\subsection{Research Topics}

This research mainly focuses on the fire risks. It aims to provide easy tools for the identification of fire risk and management for the governments, professionals, site managers and communities.

\section{BASIC FRAMEWORK}

This research refer to the UNESCO and other international literatures and 《Risk management at Heritage Sites- A Case Study of the Petra World Heritage Site》 in 2012, in which the risk assessment was mainly based on the assessment and reduce the risk of $\mathrm{CH}$ and their collections by risk analysis criteria. In this proposal the systematic application of the risk management process (Figure 1) includes the following six steps:

1. Defining the context and scope, including a documentation review as well as value, condition and management context assessment.

2. Identifying the risks.

3. Assessing the impact of each risk.

4. Identifying possible mitigation strategies.

5. Evaluating risks and mitigation strategies based on cost-benefit analysis.

6. Implementation of the strategies (preventively or actively) to tackle risks.

There are also two permanent components of the risk management process: monitoring, and communication and consultation with the different stakeholders.

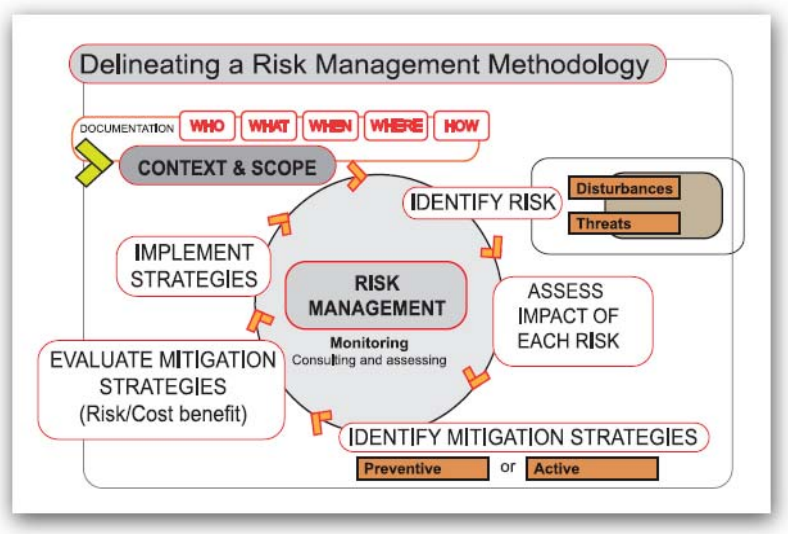

Figure 1. A risk management approach (UNESCO, 2012)

The approach shows a cycle of risk management. Consider the situation in Taiwan; value assessment, the first step of the figure 1 , is a common knowledge and necessary process in the conservation. However, the other 5 steps remain unclear in the field of conservation. This research tries to establish the hazard indicators to identify the risk. It also attempts to analyse the mitigation strategies from case study and to propose a working tool for the site managers.

issues of the researches, which includes the concerning on the historic districts as well.

\section{INVESTIGATE AND ASSESS}

This research first make an on-site survey to investigate the characteristics and value of historical buildings and monuments together with possibility of internal and external spaces vulnerable to hazard and reactive equipment. Secondly, it identifies each of the risk brought about by disaster and management. Thirdly, the communication and consultation with stakeholders on the problems of hazard factors preventing to establish monuments hazard factor assessment indicators.

From 2011 to 2013, supported by the Bureau of Cultural Heritage, the Ministry of Culture, this research implemented "Professional services centre for the conservation of $\mathrm{CH}$, division (ii)". The scope of this project is to investigate 345 374 CH of 6 counties and cities in northern Taiwan. In 2014, another project of investigating 23 national monuments in the same region was implemented. Both projects focus on evaluating their daily management, maintenance and analysis of the disaster-causing factors, summary of the investigation to establish monuments hazard factor assessment indicators.

\subsection{Site Investigation and 13 Hazard Indicators}

11 hazard indicators in 4 groups were established in 2011 and two more were added to form 13 indicators in 2013. They are:

A. Management and Maintenance System

1) Disaster history.

2) Improper placement of items.

3) Undated environmental clean-up.

4) Excessive electrical facilities, overdue wire (including too many extension).

5) Management organization and lack of staff.

6) Failure in regularly attending relevant courses or lack of certificates

B. The external environment and the characteristics of the building

1) The use of fire.

2) Improper influence from the environment.

3) Cooperation with communities.

C. Auxiliary fire-fighting equipment

1) Lack of appropriated fire-fighting equipment.

2) Lack of monitoring alarm equipment.

D. Patterns of buildings in use

1) Insufficient entrances (including those are often closed)

2) Others (to be repaired, etc.)

\subsection{Results and Discussion}

The result of investigating $345 \mathrm{CH}$ in 2011 showed that excessive electrical facilities, overdue wire (including too many extension), lack of firefighting equipment, lack of monitoring alarm equipment are the weakest of the $\mathrm{CH}$ and it leads to disasters to rescue and communications in real time. In addition, not enough number or lack of training of site managers are very common in private sites.

$374 \mathrm{CH}$ were investigated in 2012. The main hazard indicators were still the same as 2012. However, the percentage of improper placement of items, undated environment clean-up, management organization and lack of management staff and maintenance system together with the external environment was obviously reduced due to the communication and training in the past year. It shows that some risk can be mitigated by the management approach. 
On the other hand, almost all the public $\mathrm{CH}$ has established fire management and monitoring mechanism. As for private monuments, the situation is difficult to improve for lack of funding. (Table 2).

Table 2. 2011-12 Hazard indicators statistical chart

\begin{tabular}{|c|c|c|c|c|c|c|c|c|c|c|c|c|c|}
\hline \multirow{2}{*}{$\begin{array}{c}\text { Gro } \\
\text { up }\end{array}$} & \multicolumn{6}{|c|}{ A. Management and Maintenance System } & \multicolumn{3}{|c|}{$\begin{array}{l}\text { B. The external environment } \\
\text { and the characteristics of } \\
\text { the building }\end{array}$} & \multicolumn{2}{|c|}{$\begin{array}{l}\text { C. Auxiliary fire- } \\
\text { fighting equipment }\end{array}$} & \multicolumn{2}{|c|}{$\begin{array}{c}\text { D. Patterns of } \\
\text { buildings in } \\
\text { use }\end{array}$} \\
\hline & 1 & 2 & 3 & 4 & 5 & 6 & 7 & 8 & 9 & 10 & 11 & 12 & 13 \\
\hline \multirow[t]{3}{*}{$\begin{array}{c}2 \\
0 \\
1 \\
1 \\
\frown \\
345\end{array}$} & $\begin{array}{l}\text { Disaster } \\
\text { history }\end{array}$ & $\begin{array}{l}\text { Improper } \\
\text { placemen } \\
\text { t of items }\end{array}$ & $\begin{array}{l}\text { Undate } \\
\text { d } \\
\text { environ } \\
\text { mental } \\
\text { clean- } \\
\text { up }\end{array}$ & $\begin{array}{l}\text { Excessive } \\
\text { electrical } \\
\text { facilities, } \\
\text { overdue wire } \\
\text { (including too } \\
\text { many } \\
\text { extension) }\end{array}$ & $\begin{array}{l}\text { Managem } \\
\text { ent } \\
\text { organizati } \\
\text { on and } \\
\text { lack of } \\
\text { staff }\end{array}$ & & $\begin{array}{l}\text { The } \\
\text { use of } \\
\text { fire }\end{array}$ & $\begin{array}{l}\text { Improper } \\
\text { influence } \\
\text { from the } \\
\text { Environm } \\
\text { ent }\end{array}$ & $\begin{array}{l}\text { Cooperation } \\
\text { with } \\
\text { community }\end{array}$ & $\begin{array}{l}\text { Lack of } \\
\text { appropriated } \\
\text { fire-fighting } \\
\text { equipment. }\end{array}$ & $\begin{array}{l}\text { Lack of } \\
\text { monitorin } \\
\text { g alarm }\end{array}$ & & $\begin{array}{l}\text { Others } \\
\text { (to be } \\
\text { repaired } \\
\text {, etc.) }\end{array}$ \\
\hline & 6 & 39 & 73 & 98 & 94 & \multirow{2}{*}{ no } & 63 & 60 & 61 & 128 & 166 & \multirow{2}{*}{ no } & 24 \\
\hline & $2 \%$ & $11 \%$ & $21 \%$ & $28 \%$ & $27 \%$ & & $18 \%$ & $17 \%$ & $18 \%$ & $37 \%$ & $48 \%$ & & $7 \%$ \\
\hline \multirow[t]{3}{*}{$\begin{array}{c}2 \\
0 \\
1 \\
2 \\
\frown \\
374\end{array}$} & $\begin{array}{l}\text { Disaster } \\
\text { history }\end{array}$ & $\begin{array}{l}\text { Improper } \\
\text { placemen } \\
\text { t of items }\end{array}$ & $\begin{array}{l}\text { Undate } \\
\mathrm{d} \\
\text { environ } \\
\text { mental } \\
\text { clean- } \\
\text { up }\end{array}$ & $\begin{array}{l}\text { Excessive } \\
\text { electrical } \\
\text { facilities, lines } \\
\text { of old } \\
\text { (including } \\
\text { extension } \\
\text { cords) }\end{array}$ & $\begin{array}{l}\text { Managem } \\
\text { ent } \\
\text { organizati } \\
\text { on and } \\
\text { lack of } \\
\text { staff }\end{array}$ & $\begin{array}{l}\text { Failure in } \\
\text { regularly } \\
\text { attending } \\
\text { relevant } \\
\text { courses or } \\
\text { lack of } \\
\text { certificate } \\
\mathrm{s}\end{array}$ & $\begin{array}{l}\text { The } \\
\text { use of } \\
\text { fire }\end{array}$ & $\begin{array}{l}\text { Improper } \\
\text { influence } \\
\text { from the } \\
\text { Environm } \\
\text { ent }\end{array}$ & $\begin{array}{l}\text { Cooperation } \\
\text { with } \\
\text { community }\end{array}$ & $\begin{array}{l}\text { Lack of } \\
\text { appropriated } \\
\text { fire-fighting } \\
\text { equipment. }\end{array}$ & $\begin{array}{l}\text { Lack of } \\
\text { monitorin } \\
\text { g alarm }\end{array}$ & $\begin{array}{l}\text { Insuffici } \\
\text { ent } \\
\text { entrance } \\
\text { s } \\
\text { (includin } \\
\text { g those } \\
\text { are often } \\
\text { closed) }\end{array}$ & $\begin{array}{l}\text { Others } \\
\text { (to be } \\
\text { repaired } \\
\text {, etc.) }\end{array}$ \\
\hline & 4 & 18 & 45 & 93 & 55 & 24 & 61 & 23 & 32 & 103 & 109 & 8 & 147 \\
\hline & $1 \%$ & $5 \%$ & $12 \%$ & $25 \%$ & $15 \%$ & $6 \%$ & $16 \%$ & $6 \%$ & $9 \%$ & $28 \%$ & $29 \%$ & $2 \%$ & $39 \%$ \\
\hline
\end{tabular}

In 2014, continuing the process established earlier, a fourcategory of 18 hazard indicators table was designed for this research to investigate 23 national $\mathrm{CH}$. The 3 main indicators are improper placement of items, lack of staff in management organization and lack of appropriated firefighting equipment. Besides that, the scheduled training and the network within stakeholders are another 2 issues needed to improve. Among them, 7 for government agencies to manage have no significant hazard indicators, 5 of them have environment complex together with heavy traffic and more difficult to rescue in case of disaster. The performance of private $\mathrm{CH}$ is not as good as the public (Table 3).

To sum up, by the investigation on the hazard indicator of the national $\mathrm{CH}$ as follows:

1. Most $\mathrm{CH}$ was built a long time ago. It's not easy for them to meet modern code without interrupting their cultural value. The most possible chance to improve their facilities and mitigate the risk is together with the restoration but it will take a long time and a big budget.

2. Private $\mathrm{CH}$ has less potential to prepare firefighting and monitoring equipment.

3. The surroundings is an existed situation, it can be improved by well planning and management.

4. Simple actions taken by the site manager can effectively mitigate some risks. Through management effort, substantial improvement can be achieved, such as improper items, not tidy environment, and inadequate management together with community relations. It shows that investigating the site regularly will enable site manager to improve the situation of $\mathrm{CH}$.
Table 3. 18 hazard indicators statistical chart for categories (2014)

\begin{tabular}{|c|c|c|c|c|c|}
\hline 1 & 2 & 3 & 4 & 5 & 6 \\
\hline $\begin{array}{l}\text { Disaster } \\
\text { history }\end{array}$ & $\begin{array}{l}\text { Improper } \\
\text { placement } \\
\text { of items }\end{array}$ & $\begin{array}{c}\text { The use of } \\
\text { fire }\end{array}$ & $\begin{array}{c}\text { Improper } \\
\text { placement } \\
\text { of items }\end{array}$ & $\begin{array}{c}\text { Excessive } \\
\text { electrical } \\
\text { facilities, } \\
\text { lines of old } \\
\text { (including } \\
\text { extension } \\
\text { cords) } \\
\end{array}$ & $\begin{array}{l}\text { Lack of } \\
\text { fire- } \\
\text { fighting } \\
\text { equipment }\end{array}$ \\
\hline 2 & 5 & 3 & 0 & 4 & 0 \\
\hline $5 \%$ & $12 \%$ & $7 \%$ & $0 \%$ & $9 \%$ & $0 \%$ \\
\hline 7 & 8 & 9 & 10 & 11 & 12 \\
\hline $\begin{array}{l}\text { Lack of } \\
\text { monitoring } \\
\text { alarm }\end{array}$ & $\begin{array}{l}\text { Undated } \\
\text { environme } \\
\text { ntal clean- } \\
\text { up }\end{array}$ & $\begin{array}{l}\text { Manageme } \\
\mathrm{nt} \\
\text { organizatio } \\
\mathrm{n} \text { and lack } \\
\text { of staff }\end{array}$ & $\begin{array}{l}\text { Undated } \\
\text { environme } \\
\text { ntal clean- } \\
\text { up }\end{array}$ & $\begin{array}{l}\text { Failure in } \\
\text { regularly } \\
\text { attending } \\
\text { relevant } \\
\text { courses or } \\
\text { lack of } \\
\text { certificates } \\
\end{array}$ & $\begin{array}{l}\text { Insufficien } \\
\text { t entrances } \\
\text { (including } \\
\text { those are } \\
\text { often } \\
\text { closed) }\end{array}$ \\
\hline 4 & 4 & 0 & 0 & 0 & 1 \\
\hline $9 \%$ & $9 \%$ & $0 \%$ & $0 \%$ & $0 \%$ & $2 \%$ \\
\hline 13 & 14 & 15 & 16 & 17 & 18 \\
\hline $\begin{array}{l}\text { Others (to } \\
\text { be } \\
\text { repaired, } \\
\text { etc.) }\end{array}$ & $\begin{array}{l}\text { Gutters are } \\
\text { not smooth }\end{array}$ & $\begin{array}{c}\text { Doors and } \\
\text { windows } \\
\text { damaged }\end{array}$ & $\begin{array}{c}\text { Pests or } \\
\text { ants Road }\end{array}$ & $\begin{array}{l}\text { Increased } \\
\text { moisture, } \\
\text { wall } \\
\text { seepage } \\
\text { serious }\end{array}$ & $\begin{array}{c}\text { No } \\
\text { significant } \\
\text { hazards }\end{array}$ \\
\hline 7 & 1 & 1 & 2 & 2 & 7 \\
\hline $16 \%$ & $2 \%$ & $2 \%$ & $5 \%$ & $5 \%$ & $16 \%$ \\
\hline
\end{tabular}




\section{A SELF-CHECKLIST ON THE RISK ASSESSMENT FOR THE SITE MANAGER}

Disaster risk is a pressure for the conservation and will go along with the whole lifecycle of $\mathrm{CH}$. This research finds even though different indicators has their own methods to mitigate the risk, the very fundamental work is to help those site managers realize the risks on site, the ways to assess them and evaluate the progress of the improvement action.
In advance, this research proposes a self-checklist for site managers to evaluate the disaster risk of their $\mathrm{CH}$ and environment. There are five-level scoring to evaluate the disaster risk on site, -2 (very serious), -1 (serious), 0 (none), 1 (good) and 2 (very good). A high score means that $\mathrm{CH}$ is wellmaintained while a low one means improvement should be made as soon as possible (Table 4).

Table 4 .A self-checklists on the risk assessment

\begin{tabular}{|c|c|c|c|}
\hline \multicolumn{2}{|l|}{ Name : } & \multirow{2}{*}{$\begin{array}{l}\text { Assess the } \\
\text { value }\end{array}$} & \multirow{2}{*}{ Direction } \\
\hline \multicolumn{2}{|r|}{ Item } & & \\
\hline \multicolumn{4}{|l|}{ 1.Fire } \\
\hline \multirow{6}{*}{$\begin{array}{l}\text { Management } \\
\text { and } \\
\text { Maintenance } \\
\text { System }\end{array}$} & The use of fire & & $\begin{array}{l}\text { Incense, candles, incense, a gold paper, firecrackers, incense or } \\
\text { events festivals }\end{array}$ \\
\hline & Improper placement of items & & Debris build-up \\
\hline & Undated environmental clean-up & & $\begin{array}{l}\text { Cigarette butts, weeds, leaves stacked, space clutter, garbage } \\
\text { accumulation, poor drainage, moss }\end{array}$ \\
\hline & $\begin{array}{l}\text { Excessive electrical facilities, overdue } \\
\text { wire (including too many extension) }\end{array}$ & & Improper use of power outlets, extension cords used improperly \\
\hline & $\begin{array}{l}\text { Management organization and lack of } \\
\text { staff }\end{array}$ & & Idle for too long, unattended \\
\hline & $\begin{array}{l}\text { Failure in regularly attending relevant } \\
\text { courses or lack of certificates }\end{array}$ & & \\
\hline \multirow{3}{*}{$\begin{array}{l}\text { The external } \\
\text { environment } \\
\text { and the } \\
\text { characteristics } \\
\text { of the } \\
\text { building }\end{array}$} & Disaster history & & Fires, storms, floods, landslides, earthquakes \\
\hline & $\begin{array}{l}\text { Improper influence from the } \\
\text { Environment }\end{array}$ & & $\begin{array}{l}\text { Connected to the surrounding buildings, high-risk industries, } \\
\text { arcade stacking items and parking situation, remote geographical } \\
\text { environment or mountain rescue difficult situations and difficult to } \\
\text { reach }\end{array}$ \\
\hline & Cooperation with community & & $\begin{array}{l}\text { Neighbourhood watch teams, patrol teams, cultural workers, } \\
\text { monuments guard members, community people, neighbours }\end{array}$ \\
\hline \multirow{2}{*}{$\begin{array}{l}\text { Auxiliary } \\
\text { fire-fighting } \\
\text { equipment }\end{array}$} & Lack of fire-fighting equipment & & $\begin{array}{l}\text { Fire extinguishers, fire hydrant indoor and outdoor fire hydrants, } \\
\text { fire pumps, automatic sprinkler equipment, smoke detectors }\end{array}$ \\
\hline & Lack of monitoring alarm & & $\begin{array}{l}\text { Automatic fire alarm equipment, emergency radio equipment, } \\
\text { surveillance equipment, patrol boxes, security systems }\end{array}$ \\
\hline \multirow{2}{*}{$\begin{array}{l}\text { Patterns of } \\
\text { buildings in } \\
\text { use }\end{array}$} & $\begin{array}{l}\text { Insufficient entrances (including those } \\
\text { are often closed) }\end{array}$ & & Entrances locked, iron gate installation, only one export \\
\hline & Others (to be repaired, etc.) & & Serious damage, collapse \\
\hline \multicolumn{4}{|c|}{ 2. Other Disasters } \\
\hline & Gutters are not smooth & & \\
\hline & Doors and windows damaged & & \\
\hline & Pests or ants Road & & $\begin{array}{l}\text { Termites, deputy nest, sawdust, excrement, off wings, nuptial } \\
\text { flight hole decay traces }\end{array}$ \\
\hline & $\begin{array}{l}\text { Increased moisture, wall seepage } \\
\text { serious }\end{array}$ & & \\
\hline & No significant hazards & & \\
\hline
\end{tabular}




\section{CONCLUSION}

The management and maintenance of $\mathrm{CH}$ required efficient management mechanism and adequate manpower. It is operated by managing an appropriated and secure usage complemented with efficient equipment. Recently, taken the public participation concept to preserve and maintain of $\mathrm{CH}$ is an international trend so as to train site manager and community in the vicinity of a sense of identity to achieve disaster mitigation phenomenon occurs. Under this circumstance, a convenient tool for the site managers to understand and mitigation the risk of their site is full of importance.

The results are as follows,

1. Due to poor management and monitoring mechanism together with inadequate equipment, the hazard indicators of private $\mathrm{CH}$ are higher than the public. It is evident that appropriate equipment is still urgently needed for the private $\mathrm{CH}$.

2. The documentation for the maintenance and inspection on the $\mathrm{CH}$ is another important issue for the management. Furthermore, for a public usage $\mathrm{CH}$, it should pay particular attention to the internal use of fire and power facilities, the overdue wire (including too many extension) and so on, should be performed periodically (Table 4)

3. Most hazard indicators of $\mathrm{CH}$ can be mitigated mainly by management mechanism such as daily review, scheduled maintenance and integrate with appropriated equipment. The cognition and execution of site managers is the key issue for the implementation of disaster risk management.

4. The proposed self-checklist on the risk assessment can provide the site manager with an efficient tool in the implementation of risk mitigation.

\section{ACKNOWLEDGEMENTS}

Special thanks to the project "Research on the risk communication and resilience of historic district” (MOST 1032625-M-163 -001), sponsored by the Ministry of Science and Technology.

\section{REFERENCES}

1) UNESCO, Risk management at Heritage Sites- A Case Study of the Petra World Heritage Site, 2012.

2) Ya-Ning Yen 、 Su-Fen Yen , $\ulcorner$ Research of target requirement and operational organization assignment of cultural heritage disaster(III) $\lrcorner$, Ministry of Science and Technology, 2014。

3) China University of Technology , $\ulcorner$ Monuments built and settlements district calendar professional services centre (II) 」 , Bureau of Cultural Heritage ，2010-2013 。

4) China University of Technology, $\ulcorner$ Monuments built and settlements district calendar professional services centre (1)」, Bureau of Cultural Heritage , 2014 。

5) Ya-Ning Yen 、 Chin-Fang Cheng,$\ulcorner$ Disaster management and monitoring of Cultural Heritage $\lrcorner$, Kinmen County Department of Cultural Affairs, 2014。
6) Herb Stovel, 《Risk Preparedness: A Management Manual for World Cultural Heritage 》, ICCROM, 1998

7) UNESCO, 《Case Studies on Climate Change and World Heritage》, 2007

8) UNESCO, 《 Managing Disaster Risks for World Heritage》, 2010

9) UNESCO and Katholieke Universiteit Leuven, Faculty of Engineering, Raymond Lemaire International Centre for Conservation, 《Risk management at Heritage Sites- A Case Study of the Petra World Heritage Site》, 2012

10) ICOMOS-ICORP, Heritage and Resilience: Issues and Opportunities for Reducing Disaster Risks, 2013.

11) ICCROM, 《Disaster Risk management of Cultural Heritage in Urban areas - A Training Guide》, 2014. 